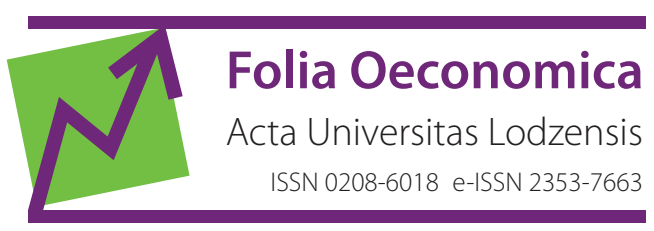

www.czasopisma.uni.lodz.pl/foe/

3(329) 2017

DOI: http://dx.doi.org/10.18778/0208-6018.329.01

\title{
Łukasz Konopielko
}

Lazarski University, Faculty of Economics and Management, Department of Economics, lukasz.konopielko@lazarski.pl

\section{Diana Radkova}

Lazarski University, Faculty of Economics and Management, rdz.diana.27@gmail.com

\section{Price dispersion and online markets maturity in Poland}

\begin{abstract}
This paper is dedicated to the issue of persistent price dispersion in real markets in the context of Polish online market development. The two channels of retail (online and offline) are observed and compared with regard to price variations determinants and their values comparison. Market efficiency comparison between both markets is also provided on the basis of theoretical background. The data collected from shops representing the two channels of retail (online and offline), for a number of commodities within the home appliance product category in Poland, has been used as a sample for the analysis. Generally, results for the Polish market are in line with similar tests performed for EU as a whole and confirm the maturity of Polish online market.
\end{abstract}

Keywords: Price dispersion, Poland, market maturity, online markets, e-commerce, Internet.

JEL: D40, L11, L81, C10 


\section{Introduction}

Online markets in Eastern Europe are developing at a rapid rate. The average annual online sales growth since 2010 achieved $35.1 \%$ comparing to $18 \%$ average for the whole Europe (E-commerce, 2015). Particularly in Poland, the percentage of individuals ordering or purchasing goods or services on the Internet for private use increased from $28.9 \%$ in 2010 to $34.2 \%$ in 2014 (GUS, 2014), while estimated share of online retail of goods in total retail of goods reached $5.4 \%$ in 2014 . However, the question remains: to what extent is this market already developed and what is its "quality"? This paper investigates the price variations in real market as a measure for market maturity, with respect to Poland. The issue of price dispersion is relevant in both traditional and online markets. Price dispersion refers to deviation of prices from the average value. This problem concerns both demand and supply holders as well as the whole market equilibrium. As online markets become more mature, more and more empirical evidence appears of higher efficiency of online markets and lower price variation rate. In the case study presented in this paper, commodities from the home appliance category in Poland are considered as the ground for the analysis: 468 price observations were obtained at the end of data gathering period. Both online and offline markets are compared with regard to price variations rates. The hypotheses are generated on the basis of theoretical expectations and are classified into two groups. The first group concentrates on the measuring of price dispersion in both retail channels; the second group tests drivers of dispersion and their relationship with prices.

The paper is built as follows: the first part provides the theoretical framework of price dispersion and expectations regarding price dispersion presence in real markets. Empirical evidence of persistent price dispersion in both online and traditional markets is presented based on literature review of previous studies; to sum up, a brief conclusion on price dispersion as a microeconomic phenomenon, which can serve as an estimator of market efficiency, is presented. The remaining part is dedicated to empirical analysis and evidence of price dispersion on the example of home appliance and consumer electronics in Poland. This section also compares achieved results to previous findings. A final conclusion mentions limitations of the study and obstacles that have been encountered, together with recommendations for future research.

\section{Price dispersion phenomenon}

The term "price dispersion" is relatively new in modern economy. Stigler was the first to mention the phenomenon of price dispersion in his article "Economics of Information" (Stigler, 1961: 213). According to Stigler, the main sources of price var- 
iation appearing in real markets are the following: search costs by market agents, property of information to become outdated over time, changing identity of buyers and sellers, size of the market, and products' heterogeneity. Price dispersion is thus defined as a variation of prices for homogeneous products across various sellers in a given market. Dispersion rate can serve as a determinant of purchase behaviour from the buyers' perspective, since the variation of prices represents the presence or absence of alternative beneficial offerings. A low rate of dispersion indicates smaller probability of the less expensive goods' purchase, since all the prices are close to the average and there are no extremes. However, when dispersion is high, buyers are more likely to put more effort into the search for the cheaper product and benefit from the purchase. From the sellers' perspective, dispersion reflects competitors' pricing strategies. For the whole market, the rate of price dispersion can show if the market is close to or far from full efficiency; the lower the dispersion rate, the closer the market is to a perfectly competitive model and the higher its efficiency. Thus investigation of the price dispersion level can be used as a benchmark for the level of a given market development.

Insufficient information about product prices forces consumers to search among various sellers, spend time and effort, which means facing considerable costs; meanwhile, cost is a discouraging feature of any activity. If we consider the discussion of price dispersion in terms of prospects theory (Kahneman, Tversky, 1979), in real markets, people underestimate the possible benefits of product search and overestimate the costs. Therefore, byers settle for the first listed price they find and forget about marginal savings, assuming that in such a way they avoid potential costs in the future (such as: time, transport, etc.) necessary to perform further search. Regardless of time loss, there is always a flow of new uninformed sellers and buyers. As they enter the market, information and prices that have already been investigated become outdated and irrelevant. Obsolete information changes conditions of search costs and the of the whole market equilibrium and makes sellers incapable of maintaining a perfect correlation of prices. In this case, the buyers are not aware of time, efforts and costs they should devote to the search either, or that they should adapt to the new equilibrium. Hence, market conditions and market stability affect price variations. As the market grows, dispersion becomes smaller, as firms that specialize in information collection arrive. Moreover, there are no purely homogeneous products across various sellers in real markets. Every seller is different; hence, the services and the commodities they offer are considered unique. Thus, information is the key element when considering price dispersion. Even in terms of theoretical framework, price dispersion definitely exists and is persistent.

The emergence of e-commerce has enriched the economic theory with a lot of new issues for discussion. As far as the price dispersion on the online markets is concerned, the theoretical framework claims that it is lower in compar- 
ison with traditional markets. The simplest logic behind this expectation is that increased availability of information and decreased search costs give a prior advantage to buyers to choose whatever seller they consider most appropriate, whereas sellers in these conditions seek to be price competitive; hence, no extreme markups are predicted to occur. Nevertheless, the results of empirical studies suggest various results and findings.

Relying on theoretical background, Bacos (1997) expected that prices in offline stores should be higher for the same items than in online shops; the author argues that the search costs differ within these two channels of retail with regard to changes in information flow and consumers' price sensitivity. The appearance of online markets is crucial for the information flow, since now consumers have to make less effort to obtain price information and product characteristics information from different sellers, as well as alternative offers in the market for a given good. Lesser effort for buyers relates to smaller search costs; comparing two channels of purchase, consumer search costs in online market are lower. Sellers know that buyers can compare prices from several retailers so that it makes no sense for them to apply high markups in order to be price competitive against the competition.

Bailey (1998) was probably the first to investigate price dispersion within the online retail channel. He took books, CDs and software items as product categories for comparison of prices between online and traditional markets (all the chosen products were considered fully homogenous). The prices were corresponding to each other in both markets. The point of his analysis was that search costs and the level of competition in the market were the determinants of dispersion rate. During the period of data (prices) collection in 1996-1997, it was observed that online prices were higher than the prices of the same products in traditional market. As Bailey explained, his first findings may conflict with the hypothetical expectations and point to higher search costs on immature online markets with low numbers of sellers. Little competition among e-retailers and consumers' search intensity was expected to increase over the time, so that more mature market would let empirically reaffirm the theory and achieve lower dispersion rates.

Later, a similar study on books and CDs by Brynjolfsson and Smith (2000), also seeking to compare dispersion in the online and traditional markets, emphasizes that e-commerce brought any market, for whatever goods and services, a possibility to have lower barriers to entry, due to alleviated infrastructure, which is simply a website page in a browser. The advantages of an online market such as lower variety of choices within the menu and absence of infrastructure issues of traditional markets contribute to a lower rate of dispersion among e-retailers. Moreover, the authors have documented a new tendency, according to which sellers in online markets tend to change 
prices more often with lesser difference than traditional retailers. This finding can also serve as a contributor to a more competitive market and expected lower price dispersion. The empirical part dedicated to the measure of posted prices by a proxy for market share accepts the hypothesis of lower dispersion favouring online markets.

As for online electronics market, Baye, Morgan and Sholten (2001) found that the number of companies posting prices tends to vary with the rate of price dispersion. An interesting case of price dispersion has been described through the analysis of online auctions by Sun and Hsu (2007), which detects another factor influencing dispersion rate. The paper concludes that sellers' reputation generally has the most significant impact on auction prices yet such auction features as: duration of bargain, the opening bid and Buy-it-now option (BIN) have a significant impact on the online auction prices. In later study regarding prices in online auctions, Pate (2006) gained the results that also confirm sellers' reputation contributing to changes in auction prices.

Shankar, Pan and Ratchford (2002) attempt to determine the drivers of price dispersion over time as well as to discover if these drivers can change. Empirical analysis showed that the provision of product information, shipping, handling and reliability were the main contributors to dispersion among e-retailers characteristics. As for market characteristics, the number of sellers was negatively correlated with the rate of dispersion; nevertheless, the authors emphasize that empirically it works only at a diminishing rate over time, and in time this effect is likely to be insignificant. Even when considering approximately similar reasons for price dispersion such as search costs, product characteristics, channel of retail, shopping convenience, brand loyalty, or level of competition, as long as e-commerce market matures, the majority of studies suggest that price dispersion streams at diminishing rate favoring the online channel. Bailey (1998), Clemons, Hann and Hitt (2002), Erevelles, Rolland and Srinivasan (2001), Lee and Gosain (2002) observed higher prices on the internet and higher price dispersion in online markets in comparison with the traditional ones. All these studies use different approaches as well as different subjects of analysis, but still their empirical results find higher price variations among e-retailers. The only similarity observed is for the time period from 1998 to 2002 . This was a very early period of e-commerce development, therefore market maturity has to be considered here again.

Nevertheless, early evidence of lower price variation in online markets also exists. For instance, Brynjolfsson and Smith (2000), Morton, Zettelmeyer and Silva-Risso (2001), Tang and Xing (2001) have documented lower dispersion rates in online markets. The study by Ancarani and Shankar (2004) discovers price dispersion for books and compact discs between three retail channels: Internet only, traditional, and multichannel. Cooper (2006) has chosen an unusual subject of analysis when comparing dispersion rates in traditional and online markets. Consistent 
with previous papers, he finds evidence of lower dispersion rate in the market for disposable contact lenses. The idea behind it was that traditional shops set prices assuming that buyers are not aware of the opportunity of buying lenses online. As a result of facilitated search costs, online price dispersion was revealed to be lower than offline with nearly $11 \%$ difference. Basically, the results showed that buyers seemed to be unaware of their options.

The paper by Rosello and Riera (2012) compares online and offline price levels and variation rates for tourism expenditures among emerging online tour agencies and existing traditional travel operators. Despite the fact that results have shown a persistent online price dispersion, it has been observed to be considerably lower among new e-retailers.

Table 1. Summary of studies that compare price dispersion rates between online and traditional markets

\begin{tabular}{|l|c|l|c|}
\hline \multicolumn{1}{|c|}{ Authors } & Year & Subject investigated & $\begin{array}{c}\text { Price dispersion } \\
\text { is higher }\end{array}$ \\
\hline Bailey & 1998 & Books, CDs, Software & Online \\
\hline Clemons, Hann and Hitt & 1998 & Airline tickets & Online \\
\hline Brynjolfsson and Smith & 2000 & Books and CDs & Offline \\
\hline Erevelles, Rolland and Srinivasan & 2001 & Vitamins & Online \\
\hline Morton, Zettelmeyer and Risso & 2001 & Cars & Offline \\
\hline Tang and Xing & 2001 & DVDS & Offline \\
\hline Clay, Krishnan, Wolff and Fernandes & 2002 & Books & Online \\
\hline Lee and Gosain & 2002 & CDs & Online \\
\hline Brown and Goolsbee & 2002 & Insurance sevices & Offline \\
\hline Ancarani and Shankar & 2004 & Books and CDs & Offline \\
\hline Cooper & 2006 & Contact lenses & Offline \\
\hline Rosello and Riera & 2012 & Travel agency services & Offline \\
\hline Sengupta and Wiggins & 2012 & Airline tickets & Offline \\
\hline Duch-Brown and Martens & 2014 & Consumer goods & Offline \\
\hline
\end{tabular}

Source: own research based on the literature review

With regard to studies on the issue of price dispersion on Eastern European markets, only one paper exists, by Szopiński and Nowacki (2014), which investigates price variation rates between domestic and foreign flight carriers in Poland, on the basis of airline tickets' prices, posted on the internet for the most popular connections. The paper reported persistent price dispersion in the market for airline tickets varying from $5.63 \%$ to $8.07 \%$ between Polish carriers and $7.70 \%$ to $20.3 \%$ between carriers from destination countries. The highest differential between absolute value of standard deviation among the two different carriers has accounted for $13.885 \%$. The conclusion suggests that dispersion is much lower among Polish carriers than among the corresponding foreign carriers for the same routes. 
The authors do not mention any reasons that would account for such a big gap between prices.

When reviewing the literature on price dispersion chronologically, more recent papers contradict the findings of research performed at the time when e-commerce was still in its infancy. For instance, earlier papers describe higher online dispersion; whereas the results of more recent papers are in accordance with the initial theoretical expectations regarding lower online dispersion. In more mature online markets, market players adapt to the conditions of perfect information and very low search costs, which makes the suppliers aim at being price-competitive and still survive on the market, so that sellers keep prices on approximately equal level without considerable markups. This notion can be treated as one of the online markets' maturity characteristics: mature markets experience a decrease in price variations rate.

\section{Empirical evidence from Poland}

The main objective of this paper is to investigate price dispersion in real markets as well as to apply basic theoretical expectations to practical situations, and to compare the results to previous studies. Specifically, the market of household appliance electronics in Poland is observed. Household appliance goods are divided into three subgroups: major home appliances, or white goods; small home appliances; consumer electronics, or brown goods. The point is to use a dataset consisting of prices for chosen types of electronic goods as the main subject of the analysis, in order to detect the presence of dispersions and highlight external and internal factors that may influence prices. By the term "external", market factors are basically implied, whereas internal determinant may underlie in the specification of the commodities.

Table 2. Hypotheses classification

\begin{tabular}{|c|l|l|l|}
\hline \multicolumn{2}{|c|}{$\begin{array}{l}\text { Price dispersion measurements } \\
\text { and comparison }\end{array}$} & \multicolumn{2}{|c|}{ Sources and influence } \\
\hline $\mathrm{H}_{0}$ & $\begin{array}{l}\text { Price dispersion is present in both online } \\
\text { and traditional markets. }\end{array}$ & $\mathrm{H}_{2}$ & $\begin{array}{l}\text { Sellers' reputation impacts price varia- } \\
\text { tion rate. }\end{array}$ \\
\hline $\mathrm{H}_{1}$ & $\begin{array}{l}\text { The rate of price dispersion is lower in on- } \\
\text { line shops than in corresponding offline } \\
\text { ones. }\end{array}$ & $\mathrm{H}_{3}$ & Product reputation affects price variation. \\
\hline & $\mathrm{H}_{4}$ & $\begin{array}{l}\text { Number of sellers is negatively correlated } \\
\text { to price dispersion rate. }\end{array}$ \\
\hline
\end{tabular}


Considering the theoretical background provided in the previous section, it is most obvious and relevant to achieve empirical evidence of lower dispersion rate in online markets and to define its main determinants. The set of hypotheses is divided into dispersion rate measurements and its comparison $\left(\mathrm{H}_{0}, \mathrm{H}_{1}\right)$ and checking for sources of dispersion $\left(\mathrm{H}_{2}, \mathrm{H}_{3}, \mathrm{H}_{4}\right)$. Table 2 represents hypothesis classification.

As long as hypotheses are classified with regard to the aims of the analysis, two different methodological approaches will be applied for each group of hypotheses.

Methodological approaches in studies for price dispersion vary, however the coefficient of variation has been used by Ghose and Yao (2011), Sengupta and Wiggins (2012), Duch-Brown and Martins (2014), Szopiński and Nowacki (2014), therefore, probably, it is the best known estimation method. In this analysis of price dispersion, relative standard deviation is considered a primary method of measurement. All the hypotheses from the group one will be tested with descriptive statistics calculations. When calculating relative standard deviation, actual prices will be put in a dataset and analysed with software. With respect to the hypotheses from group two a common tool of investigating sources of price variation - econometric modelling - has been observed on the basis of literature review. Shankar, Pan, and Ratchford (2002), Cooper (2006), Leong (2013), Sengupta and Wiggins (2012), Duch-Brown and Martens (2014) used linear regression models as a methodology approach of detecting factors influencing price variation. Following the study by Shankar, Pan and Ratchford (2002), cluster analysis of the regression will be used as a helping feature. The following log-linear equation has been generated:

$$
\begin{gathered}
\text { Model 1 } \\
\ln \left(P_{j, k}\right)=\alpha_{0}+\alpha_{1} \cdot s h_{r_{k}}+\alpha_{2} \cdot p r_{r_{j}}+\alpha_{3} \cdot n o s h_{j}+\alpha_{4} \cdot \gamma_{\text {ON,OFF }}+\alpha_{5} \cdot \gamma_{\text {ovens }}+\alpha_{6} \cdot \gamma_{\text {refig }}+ \\
\alpha_{7} \cdot \gamma_{\text {wash }_{\text {mach }}}+\alpha_{8} \cdot \gamma_{\text {dish }_{\text {wash }}}+\alpha_{9} \cdot \gamma_{\text {smart }}
\end{gathered}
$$

Price is used as a dependent variable of the model, since the primary interest lies in determining which factors affect it and to what degree. Price has been put into logarithmic terms in order to observe percentage change in dependent variable with each unit change in independent (explanatory) variables. Sellers' reputation, product reputation, level of competition, dummies for product characteristics and channel of retail have been chosen as explanatory variables.

Dummies for product characteristics and channel of retail are plugged in on purpose: for the first group of hypotheses (in order to use "sort by" functions), and for the second group of hypotheses (with a view to check if product category may impact price variation). 
Table 3. Variables description

\begin{tabular}{|c|l|}
\hline $\begin{array}{c}\text { Variable } \\
\text { name }\end{array}$ & \multicolumn{1}{c|}{ Explanation } \\
\hline$P_{j, k}$ & Price for a good $\mathrm{j}$ in the shop $\mathrm{k}$ \\
\hline $\mathrm{sh} \_\mathrm{r}(\mathrm{k})$ & Seller's reputation measured as a rate of shop $\mathrm{k}$ \\
\hline$p r_{r_{j}}$ & Product reputation measured as a rate of product $\mathrm{j}$ \\
\hline$n o s h_{j}$ & Number of sellers that offer a good $\mathrm{j}$ as a measure of competition level \\
\hline$\gamma_{\text {ON,OFF }}$ & $\begin{array}{l}\text { Dummy that indicates whether the shop operates on the online market or the tradi- } \\
\text { tional one. } \\
1-\text { indicates that the shop is online } \\
0-\text { indicates that the shop is in-store }\end{array}$ \\
\hline$\gamma_{n}$ & $\begin{array}{l}\text { Dummy that indicates whether commodities refer to a specific group of product cat- } \\
\text { egories (7) such as refrigerators, washing machines, dish washers, TV sets, smart- } \\
\text { phones, small home appliances (indicated as sma), and ovens. } \\
1-\text { indicates that the good is in its category } \\
0-\text { otherwise }\end{array}$ \\
\hline$\alpha_{n}$ & Regression coefficients \\
\hline$\varepsilon$ & Error term that measures unobservable factors and model bias \\
\hline
\end{tabular}

Source: own research

A primary source of data has been used in this study in order to gain empirical results for the set of hypotheses; all the data has been collected manually. All in all, 396 price observations have been collected for the analysis. These are the observations for 33 product categories from 8 online and 4 physical shops in Poland. Availability of the commodity from all the stores has been a mandatory requirement. Initial list of commodities comprised 72 goods; subsequently, the list was filtered out in order to gain cross section data of 12 shops. All the price observations have been collected in domestic currency, i.e. Polish Zloty at the end of the first quarter of 2015. Data gathering process consisted of several steps. The first one was the choice of shops and creation of the list of commodities. Strictly, only retail shops and commodities referring to home appliances match the field of study. Initially, the number of units was the same in each of the three groups of commodities. However, as soon as the filter sorted the results, among the leftover 33 commodities suiting to cross-section data distribution, 11 were form a group of consumer electronics, or brown goods, 4 refered to small home appliances, and the remaining 18 were major home appliances, or white goods. The prices from in-stores like Komputronik, Saturn, Media Markt, and RTV Euro AGD were collected manually with the help of shop assistants, shop catalogue or a direct phone call to the shop. All the prices have been added into final list of observations. In case of the online shops, things were much easier due to the existence of price comparison websites; in this case, Ceneo.pl has been used as a source of data (Ceneo.pl, 2015). Price collection from price 
comparison websites is a common practice when investigating price dispersion rates. For instance, Shankar, Pan and Ratchford (2002) used Bizrate.com, Baye, Morgan and Shulton (2001) referred to Shopping.com in their studies. Following their example, Polish equivalent of such websites has been found and used as data source. Sellers reputation (shop rate), product reputation (product rate) and product reputation (product rate) values have also been collected from ceneo.pl platform.

\subsection{Empirical evidence of the hypotheses of the first group}

Table 4 represents final results of price dispersion rates in both markets.

Table 4. Descriptive statistics of price in online and traditional markets

\begin{tabular}{|l|c|c|c|}
\hline \multicolumn{1}{|c|}{ Descriptive statistics } & Online (264) & Offline (132) & Lower value is: \\
\hline Mean & 1449.82 & 1450.6 & Online \\
\hline Medium & 1299.495 & 1309 & Online \\
\hline Minimum & 61 & 67.9 & Online \\
\hline Maximum & 4022.22 & 4049 & Online \\
\hline Range & 3961.22 & 3981.1 & Online \\
\hline Standard Deviation & 872.468 & 865.468 & Offline \\
\hline Relative standard deviation, \% & 60.1775 & 59.6628 & Offline \\
\hline
\end{tabular}

Source: own calculations

This step allows us to conclude that zero hypothesis is accepted since relative standard deviation (proxy to measure dispersion rate) does not equal zero in either of the retail channels: $60.2 \%$ for online markets and $59.7 \%$ for the traditional ones (Table 4). Generally speaking, dispersion rate is really high if compared, for instance with $5.63 \%$ and $20.3 \%$ of price variations in airline tickets sales in the study by Szopiński and Nowacki (2014). When discussing hypothesis which picks out the market with a lower rate of dispersion, the last column in table 4, shows that price variation is higher in the online market. However, it is worth mentioning that the first run of descriptive statistics does not account for different product categories and their heterogeneity; so, in order to gain more reliable and accurate results, the problem of product classification should be solved.

The second run is going to distinguish prices by product category with the use of dummies indicating retail channel and commodity characteristics. Table 5 shows the rates achieved from the second run of descriptive statistics.

After commodities characteristics were held fixed, five out of seven product categories indicated a lower relative deviation rate than in corresponding offline market; except for goods from the smartphones and washing machines category (Table 5). Yet, the lowest rate of price variation was found at $18.10 \%$ for washing 
machines and the highest rate of dispersion was at $77.5 \%$ for small home appliances category (both in physical stores). As long as majority of product categories favour lower rate of dispersion in online markets, the hypothesis one is accepted.

Table 5. Descriptive statistics of price in online and traditional markets by product category

\begin{tabular}{|c|c|c|c|}
\hline Descriptive statistics & Online (264) & Offline (132) & Lower value is: \\
\hline \multicolumn{4}{|c|}{ Small home appliances } \\
\hline Mean & 488.3797 & 530.7975 & Online \\
\hline Medium & 424 & 487.7 & Online \\
\hline Range & 1138 & 1131.1 & Offline \\
\hline Relative standard deviation, $\%$ & 76.20433 & 77.50612 & Online \\
\hline \multicolumn{4}{|l|}{ Smartphones } \\
\hline Mean & 1278.128 & 1247.25 & Offline \\
\hline Medium & 1231.25 & 1198.5 & Offline \\
\hline Range & 2343.98 & 1960 & Offline \\
\hline Relative standard deviation, \% & 58.38473 & 56.82995 & Offline \\
\hline \multicolumn{4}{|c|}{ Tv-sets } \\
\hline Mean & 2267.161 & 2278.74 & Online \\
\hline Medium & 1661.4 & 1691.89 & Online \\
\hline Range & 2793.23 & 2810 & Online \\
\hline Relative standard deviation, $\%$ & 50.75589 & 51.23243 & Online \\
\hline \multicolumn{4}{|c|}{ Refrigirators } \\
\hline Mean & 2130.8 & 2139.736 & Online \\
\hline Medium & 2187.4 & 2177.99 & Offline \\
\hline Range & 2333.09 & 2408.02 & Online \\
\hline Relative standard deviation, \% & 37.09722 & 38.15863 & Online \\
\hline \multicolumn{4}{|c|}{ Dish washers } \\
\hline Mean & 1299.669 & 1299.291 & Offline \\
\hline Medium & 1322 & 1319 & Offline \\
\hline Range & 660.5601 & 694 & Online \\
\hline Relative standard deviation, $\%$ & 21.809 & 22.11982 & Online \\
\hline \multicolumn{4}{|c|}{ Washing machines } \\
\hline Mean & 1180.493 & 1189.498 & Online \\
\hline Medium & 1259.96 & 1240.65 & Offline \\
\hline Range & 927 & 706.16 & Offline \\
\hline Relative standard deviation, $\%$ & 19.81226 & 18.0838 & Offline \\
\hline \multicolumn{4}{|c|}{ Ovens } \\
\hline Mean & 1515.514 & 1509.58 & Offline \\
\hline Medium & 1399.05 & 1359.05 & Offline \\
\hline Range & 2123.05 & 2070 & Offline \\
\hline Relative standard deviation, $\%$ & 52.26113 & 52.91494 & Online \\
\hline
\end{tabular}

Note: the number in brackets in columns' names indicating the channel of retail shows the number of price observations 


\subsection{Empirical evidence of the hypotheses of the second group}

The second group of hypotheses aims to determine drivers of price dispersion in both markets. In order to accept or reject all the hypotheses from the second group, it would be enough to run OLS regression and analyze general model reliability and statistical significance of explanatory variables and check coefficient signs in case of hypothesis four. The final equation includes price in logarithmic terms as a dependent variable, whereas product and sellers' reputation, level of competition, dummy indicating channel of retail and small home appliance commodities serve as independent variables:

$$
\ln \left(P_{j, k}\right)=\alpha_{0}+\alpha_{1} \cdot s h_{r_{k}}+\alpha_{2} \cdot p r_{r_{j}}+\alpha_{3} \cdot \operatorname{nosh}_{j}+\alpha_{4} \cdot \gamma_{O N, O F F}+\alpha_{10} \cdot \gamma_{s m a}+\varepsilon .
$$

Table 6. Presentation of OLS regression output

\begin{tabular}{|c|c|c|c|}
\hline \multicolumn{4}{|c|}{$\begin{array}{l}\text { Number of observations }=396 \\
F(5,32)=6.20 \\
\text { Prob }>F=0.0004 \\
\text { R-squared }=0.4330\end{array}$} \\
\hline Inprice & Coefficient & t-statistic & $P>|t|$ \\
\hline pr_r & -0.4681863 & -2.17 & 0.037 \\
\hline nosh & -0.0017269 & -0.15 & 0.881 \\
\hline sh_r & -0.1728411 & -4.16 & 0.000 \\
\hline onoff & -0.0188441 & -2.86 & 0.007 \\
\hline Sma & -1.33511 & -2.83 & 0.008 \\
\hline Cons & 9.475434 & 8.33 & 0.000 \\
\hline
\end{tabular}

Source: own calculations

All the p-values of coefficients are treated as statistically significant except for the level of competition variable which has not been excluded earlier, since the hypothesis four focuses on its relationship with dependent variable. Product and sellers' reputation variables are treated as statistically significant. Hence, the hypotheses two and three are accepted and both product and shop rates influence price variations. Negative signs of product and sellers' reputation and the level of competition variables show that the more popular the product and the retailer, and the higher the number of sellers who offer a commodity, the lower the price dispersion, since there is a negative, linear relationship between these explanatory variables and price. Hypothesis four is accepted which can be paraphrased as follows: as the number of sellers, or the rate of competition grows, price variation diminishes.

To sum up, all the hypotheses from the second group have been accepted in conformity with expectations and empirical studies dedicated to similar issues that have been mentioned earlier. Econometric analysis reaffirmed anticipation 
in regard to external factors that may influence price variations, such as: product, seller's reputations, retail channel and rate of competition as well as internal factors which underlie commodity specification assignment in case of small home appliance goods.

When comparing exact values of price dispersion rate, Duch-Brown and Martens' (2014) paper can be taken as a reference for collation, since their analysis has been undertaken? In the EU and home appliance goods were the subject of investigation. Not all the product categories from this study can be compared to theirs, but for TVs, refrigerators, ovens and washing machines categories coefficients of variations can be collated.

Table 7. Relative standard deviation values comparison for chosen product categories, \%

\begin{tabular}{|l|c|c|c|}
\hline \multicolumn{1}{|c|}{ Product category } & This paper & $\begin{array}{c}\text { Duch-Brown } \\
\text { and Martens (2014) }\end{array}$ & $\begin{array}{c}\text { Differentials } \\
\text { in studies }\end{array}$ \\
\hline \multirow{3}{*}{ TVs } & $51.23^{*}$ & $60.80^{*}$ & $9.57^{*}$ \\
& 50.76 & 59.80 & 9.04 \\
\hline \multirow{3}{*}{ Refrigerators } & $(0.48)$ & $(1.00)$ & $8.24^{*}$ \\
& $38.16^{*}$ & $46.40^{*}$ & 10.80 \\
\hline \multirow{3}{*}{ Washing machines } & 37.10 & 47.90 & $15.92^{*}$ \\
& $(1.06)$ & $(1.50)$ & 15.29 \\
\hline \multirow{3}{*}{ Ovens } & $18.08^{*}$ & $34.00^{*}$ & $30.09^{*}$ \\
& 19.81 & 35.10 & 30.44 \\
\hline
\end{tabular}

Note: A star next to some values indicates that this value refers to physical stores. The number in brackets is a module difference between the two values in one cell.

Source: own calculation and calculation from the report by Duch-Brown and Martens (2014)

In summary, the results for TVs, washing machines and ovens categories collate identically and prefer similar channels of retail. However, in case of refrigerators, there is a discrepancy. Moreover, all price differentials between the two papers are very small: the highest differential accounts for $0.63 \%$ difference in case of washing machines and $0.35 \%$ is the lowest for ovens.

\section{Conclusion}

In conclusion, empirical price dispersion rate exists in both markets. Empirical evidence on the example of home appliance and consumer electronics commodities in Poland proves that price dispersion is lower in online markets. Results gained 
in this study are consistent with previous studies on the issue of price variation. Nevertheless, relatively small sample size leaves space for improvement and further investigation could be suggested with increased amount of information.

If considering probable drivers of price dispersion in both physical and online markets, the results of econometric analysis suggest that product and sellers' reputation, commodity's category and a channel of retail are perceived as drivers of price variations, as it has been expected in the section about hypotheses settlement. As it has been mentioned in theoretical framework review, online markets' maturity also has an impact on the level of price variations. In line with theoretical expectations and previous studies, this research of online markets in Poland brings successful evidence of a mature online market.

\section{References}

Ancarani F., Shankar V . (2004), Price Levels and Price Dispersion Within and Across Multiple Retailer Types: Further Evidence and Extension, "Journal of the Academy of Marketing Science", no. 32, pp. 176-187.

Bailey J.P. (1998), Electronic commerce: Prices and consumer issues for three products: Books, Compact Discs, and Software, "Organisation for Economic Co-Operation and Development", vol. 4, Paris.

Bakos J.Y. (1997), Reducing buyer search costs: Implications for electronic market places, "Management Science", no. 43, pp. 1676-1692.

Baye M.R., Morgan J., Scholten P. (2001), Price Dispersion in the Small and in the Large: Evidence from an Internet Comparison Site, "The Journal of Industrial Economics", no. 52, pp. 463-496.

Brown J.R., Goolsbee A. (2002), Does the Internet Make Markets More Competitive? Evidence from the Life Insurance Industry, "Journal of Political Economy”, vol. 110, no. 3, pp. 481-507.

Brynjolfsson E., Smith M.D. (2000), Frictionless Commerce? A Comparison of Internet and Conventional Retailers, "Management Science", no. 46, pp. 563-585.

Clay K., Krisham R., Wolff E., Fernandes D. (2002), Retail strategies on the web: Price and non-price competition in the online book industry, "The Journal of Industrial Economics", no. 50(3), pp. 351-367.

Clemons E., Hann I., Hitt L. (2002), Price Dispersion and Differentiation in Online Travel: An Empirical Investigation, "Management Science", no. 48, pp. 543-549.

Cooper J. (2006), Prices and Price Dispersion in Online and Offline Markets for Contact Lenses, "Federal Trade Commission Bureau of Economics Working Paper", no. 283.

Duch-Brown N., Martens B. (2014), Consumer Benefits from the EU Digital Single Market: Evidence from Household Appliances Markets, "Digital Economy Working Paper" no. 3.

E-commerce (2015), Eastern European B2C E-commerce Report 2015, Ecommerce Foundation, Brussels.

Erevelles S., Rolland E., Srinivasan S. (2001), Are Prices Really Lower on The Internet?: An Analysis of The Vitamin Industry, "Working Paper, University of California".

Ghose A., Yao Y. (2011), Using transaction prices to re-examine price dispersion in electronic markets, "Information Systems Research", no. 22, pp. 269-288.

GUS (2014), Społeczeństwo informacyjne w Polsce. Wyniki badań statystycznych z lat 20102014 [Information Society in Poland. Results of statistical research over 2010-2014 peri$o d]$, Szczecin. 
Kahneman D., Tversky A. (1979), Prospect Theory: An Analysis of Decision Under Risk, "Econometrica", no. 47, pp. 263-291.

Lee Z., Gosain S. (2002), A Longitudinal Price Comparison for Music CDs in Electronics and Brick-and-Mortar Markets: Pricing Strategies in Emergent Electronic Commerce, "Journal of Business Strategies", no. 19, pp. 55-71.

Leong J. (2013), Price Dispersion in Online Grocery Stores: An Analysis of the UK Market, "Atlantic Economic Journal", no. 41(2), pp. 185-187.

Morton F.S., Zettelmeyer F., Silva-Risso J. (2001), Internet Car Retailing, "Journal of Industrial Economics", no. 49, pp. 501-519.

Nellis J., Parker D. (2002), Principles of business economics, Pearson Education Ltd, New York.

Pan X., Rachford B.T., Shankar V . (2004), Price dispersion on the internet: A review and directions for future research, "Journal of Interactive Marketing", no. 18, pp. 116-135.

Pate J. (2006), Seller reputation as a determinant of price in online auction: Theory and evidence from gift card sales, "Working Paper", Loyola Marymount University, Los Angeles.

Rosello J., Riera A. (2012), Pricing European Package Tours: The Impact of New Distribution Channels and Low-Cost Airlines, "Tourism Economics", no. 18, pp. 265-279.

Sengupta A., Wiggins S. (2012), Comparing Price Dispersion on and off the Internet Using Airline Transaction Data, „Review of Network Economics”, no. 11, doi:10.1515/1446-9022.1244.

Shankar V., Pan X., Ratchford B.T. (2002), Do Drivers of Online Price Dispersion Change as Online Markets Grow?, "Working Paper", University of Maryland, College Park.

Stigler G. (1961), The Economics of Information, "Journal of Political Economy”, no. 69, pp. 213-225.

Sun C.H., Hsu M.F. (2007), The Determinants of Price in Online Auctions: More Evidence from Quantile Regression, "Working Paper 07-18 Department of Economics".

Szopiński T., Nowacki R. (2014), Plane Ticket Price Dispersion in the Online Selling System in Poland, „Contemporary Economics”, no. 8, pp. 207-218.

Tang F., Xing X . (2001), Will the growth of multi-channel retailing diminish the pricing efficiency of the web?, "Journal of Retailing", no. 77, pp. 319-333.

\section{Dyspersja cenowa i dojrzałość rynków online w Polsce}

Streszczenie: Artykuł dotyczy zjawiska trwałej dyspersji cenowej w kontekście rozwoju rynków online w Polsce. Obserwacja dwóch kanałów sprzedaży (online i offline) ma na celu dokonanie porównania determinantów zmienności cenowej i ich kompozycji. Bazując na przesłankach teoretycznych, dokonano również porównania efektywności obu rynków. Dane do analizy zostały zabrane w sieciach dystrybucji dóbr AGD zarówno online, jak i offline. Rezultaty są zbliżone do podobnych, uzyskiwanych na innych rynkach Unii Europejskiej i wskazują na dojrzałość polskiego rynku sprzedaży online.

Słowa kluczowe: dyspersja cenowa, Polska, dojrzałość rynku, rynki online, e-handel, Internet

JEL: D40, L11, L81, C10

\begin{tabular}{|l|l|}
\hline \multirow{2}{*}{ OPEN ACCESS } & $\begin{array}{l}\text { C by the author, licensee Łódź University - Łódź University Press, Łódź, Poland. } \\
\text { This article is an open access article distributed under the terms and conditions } \\
\text { of the Creative Commons Attribution license CC-BY } \\
\text { (http://creativecommons.org/licenses/by/3.0/) }\end{array}$ \\
\cline { 2 - 2 } & Received: 2016-06-09; verified: 2016-08-30. Accepted: 2017-07-31 \\
\hline
\end{tabular}

